\title{
Imperiumin järki:
} Financial Timesin poliittinen järjestys

Pääomat, tavarat ja palvelut ovat saaneet liikkua kansallisten rajojen yli entistä vapaammin 1970-luvulta lähtien. Samalla uudet teknologiat ovat tehneet mahdolliseksi entistä kansainvälisemmän teollisen tuotannon ja globaalit reaaliaikaiset pääomamarkkinat. Kansainväliset suuryritykset ovat kasvattaneet valtaansa ja niiden intressit ovat tulleet entistä painokkaammiksi politiikassa. Kun raha on

Artikkelissa pohditaan uusia imperiumin ja imperialismin teorioita, erityisesti Michael Hardtin ja Antonio Negrin teesiä uudesta imperiumista ja sen valtajärjestelmästä, ja mietitään, miten niitä voitaisiin soveltaa globalisaation tuottamien kansainvälisten julkisten tilojen ymmärtämiseksi. Artikkelissa analysoidaan genealogisesti Financial Times -lehden vaaliuutisointia 26 maan kansallisissa parlamenttivaaleissa 2000-2005. FT:n tuottama poliittinen järjestys nähdään uuden imperiumin järkenä, jossa vaikuttavat edelleen myös edesmenneen britti-imperiumin poliittisen hallinnan käytännöt ja paradoksit. Artikkeli ehdottaakin, että kansainvälisiä julkisia tiloja voisi tutkia ja ymmärtää poliittisen hallinnan ja kurin tuottajina. haastanut kansalliset tilat, ylittänyt rajoja ja luonut uusia yhteyksiä eri paikkojen välillä, myös valtioiden nähdään muuttuneen kilpailuvaltioiksi, jotka kilpailevat pääomista ja sijoituksista.

Yksi suuri huoli on talouden ja demokratian tilojen erkaantuminen toisistaan: rahan mittakaava on usein globaali ja demokratian kansallinen. Tämä huoli ulottuu myös kansallisiin julkisuuksiin. Kun kansalliset demokratiat kohtaavat kansainvälistyvän talouden tuomia paineita, myös kansalliset julkiset tilat ovat paineiden alla (Habermas 1999; Frazer 2006). Julkisuus on ollut perinteisesti

pitkälle kansallisesti värittynyttä ja jäsentynyttä. Kuten esimerkiksi Nancy Frazer (2006) on tuonut esiin, julkisen sfäärin teorioita on ajateltava uudelleen, koska ne ovat perustuneet westfalenilaiselle kansantaloudelle, valtiolle ja demokratialle. Nyt talous ja markkinat ovat erkaantumassa poliittisesta päätöksenteosta, demokratiasta ja myös niistä julkisista tiloista, jotka ovat osaltaan mahdollistaneet demokratioiden toiminnan.

Tarkastelen tässä artikkelissa erityisesti kansainvälisten pääomien merkitystä ja suhdetta julkisiin tiloihin: miten kansainvälisen talouden voimat näkyvät julkisissa tiloissa ja millaisia uusia julkisia tiloja ne tuottavat (vrt. Kantola 2001)? Tarkasteltavana on yksi julkinen tila, jossa kansainvälistyneiden pääomien ääni on voimakkaimmillaan: Financial Times -lehden (FT) kansainvälinen talousjournalismi. Tutkin FT:n tapaa tuottaa poliittista järkeä ja pohdin sen valossa, miten kansainvälinen talousjournalismi toimii julkisena tilana ja miten kansainvälistyvien julkisten tilojen merkitystä voisi ymmärtää ja analysoida uudessa tilanteessa. 


\section{Teesi uudesta imperialismista}

Yksi tulkinta muutoksesta on globalisaation tulkitseminen imperialismiksi tai imperiumin vallaksi. Molemmat käsitteet, sekä imperialismi että imperiumi, on nostettu esiin poliittisen kirjon eri päissä ennen muuta Yhdysvaltojen globaalia johtoasemaa selitettäessä.

Käytännöllis-poliittiset yhteiskuntatieteilijät miettivät usein amerikkalaista imperialismia tekijän näkökulmasta: mitä Yhdysvaltojen tulisi tehdä vallallaan ja miten sitä pitäisi käyttää? Joidenkin mielestä Yhdysvaltojen tulisi pitää läntisten arvojen lippua korkealla (Ferguson 2005), toiset vaativat, että maan tulisi luopua yrityksestä hallita koko maailmaa (Mann 2005). Kriittiset äänet näkevät amerikkalaisen imperialismin Yhdysvaltojen taloudellisen valtapolitiikan muodoksi (Bacevitch 2005) tai uudeksi imperialismiksi, jota kansainvälistyneiden pääomien tarpeet ajavat eteenpäin (Harvey 2003; Hesmondhalgh tässä lehdessä).

Yhteiskuntateoriassa imperialismin käsitteen uuteen teoreettiseen tulemiseen on vaikuttanut ehkä eniten Michael Hardtin ja Antonio Negrin (2000, xiv-xv) teesi imperiumista, joka perustuu globaalin ja universaalin järjestyksen tuottamiselle. Hardt ja Negri esittävät, että Yhdysvaltojen imperiumi eroaa perusteiltaan 1800-luvun imperiumeista siinä, että imperiumien välisen valtakilpailun on korvannut yksi logiikka ja järki. Imperiumin järjestyksen tuottavat ei-alueelliset hallinnan ja vallan muodot, jotka eivät ole sitoutuneet alueellisiin instituutioihin ja valtarakenteisiin. Imperiumia voi pitää pyrkimyksenä luoda yleispätevä poliittinen järki, jossa eri logiikat sovitetaan yhteen niin, että niistä muodostuu globaali poliittinen järjestys hierarkioineen (emt. 13).

Hardtin ja Negrin imperiumin teorian kiinnostava anti on perusajatus siitä, että imperiumin valta toteutuu foucault'laisten globaaleiksi pyrkivien hallinnan rationaliteettien kautta. Uuden imperialismin ytimessä on ajatus globaalista järjestyksestä, joka luodaan tuottamalla poliittista järkeä, joka sekä kutsuu että kurittaa; tuottaa poliittisia lupauksia poliittisesta toimijuudesta ja samalla uusia hallinnan ja kontrollin muotoja. Imperiumia pitävät yllä lupaukset vapaudesta, rauhasta ja oikeudenmukaisesta sodasta, joka muuntaa sodat poliisitoimeksi ja politiikan ihmisoikeuksien toteuttamiseksi.

Hardtin ja Negrin teesi on herättänyt laajaa kriittistä keskustelua ja sitä on kritisoitu täysin perustellusti sen epähistoriallisuudesta ja teoreettisesta epämääräisyydestä (esim. Balakrisnan 2003; Harvey 2003, 169). Kriittistä teoriaa edustava David Harvey $(2005,7)$ kysyy, mitä uutta Hardtin ja Negrin kuvaamassa imperialismissa 
oikeastaan on? Harvey itse edustaa varsin klassista marxilaista tulkintaa, jonka mukaan nykyinen Yhdysvaltain talousetujen johtama imperialismi on hyvin samantyyppistä kuin britti-imperiumin aikanaan harjoittama imperialismi ja perustuu pakolle etsiä uusia sijoitusmahdollisuuksia kasautuville pääomille (emt. 180-182).

Toisaalta myös kriittisen teorian piirissä on esitetty, että imperialismin luonne on muuttunut. Tämä niin sanotun uuden imperialismin teesi alkoi kehittyä jo 1970-luvulla (Arrighi 2003; Panitch 2000). Yhdysvaltain hegemonian alla kehittynyt suorien investointien kasvu sai jo 1970-luvulla teoriat imperialismista kansallisvaltioiden välisen valtakilpailun jatkeena ja muotona näyttämään Giovanni Arrighin sanoin "järjettömiltä" ja kehittämään uutta teesiä ei-territoriaalisesta imperialismista, joka ei olisi vain nationalismin jatketta (Arrighi 1978; 2003, 35). Vaikka Arrighi (2003) polemisoi ankarasti Hardtin ja Negrin tulkintaa, hän toisaalta edustaa tietyiltä osin hyvin samantyyppistä ajattelua, jonka mukaan uusi Yhdysvaltojen johtoasemalle nojautuva imperialismi ei perustu alueellisesti rajatuille valloituksille, vaan toimii enemmänkin sijoituspääomien tarpeiden mukaisesti ei-alueellisena logiikkana.

Oman lisänsä imperialismin teorioihin tuo se, että uuden imperialismin yhteyttä britti-imperiumiin ei kannata ehkä sittenkään täysin unohtaa. Uuden ei-alueellisen imperialismin teeseillä näyttäisi olevan samoja piirteitä 1800-luvun britti-imperiumista tehtyihin analyyseihin, joissa muun muassa Hannah Arendt ja Karl Polanyi korostivat imperiumin taloudellista luonnetta ja sen tapaa tuottaa taloudellista järjestystä (Arendt 1966; Polanyi [1944] 1974; Cain ja Hopkins 1994; Porter 1996, 130-140).

Ei siis näytä siltä, että toistaiseksi olisi hahmottunut selkeää uuden imperialismin teoriaa, jolla globalisaatiota voidaan selittää. Sen sijaan keskustelussa risteilee useita erilaisia teoreettisia näkemyksiä, jotka pyrkivät hahmottamaan globalisaation tuottamaa uutta tilannetta imperialismin käsitteiden kautta. Näistä ehkä kaksi hypoteesia on tässä keskeisintä:

(i) Uusi imperialismi on luonteeltaan ei-alueellista: se ei ole suoraan sidottu tietyn kansallisvaltion laajentumispyrkimyksiin, vaan noudattelee enemmänkin sijoituspääomien ja uusia toiminta-alueita etsivän markkinatalouden toimintalogiikkaa.

(ii) Uuden imperialismin järjestys tuotetaan ja legitimoidaan symbolisesti erilaisissa julkisissa tiloissa ja tämän symbolisen järjestyksen tuottaminen on oleellinen uuden imperialismin ulottuvuus.

Näillä hypoteeseilla on myös oma antinsa julkisuuksien ja median tutkijoille. Jos on olemassa uusi ei-alueellinen imperialismi, jonka valta perustuu hallinnan rationaliteeteille, miten ja missä sen järjestys tuotetaan? Mitkä ovat niitä paikkoja, joissa uuden globaalin järjestyksen lupaukset ja imperatiivit tuotetaan? Pääomien ja talouden vapauttamisen myötä maailmaan on muodostumassa uusi järjestys, jossa talouden ja markkinoiden logiikka haastaa valtioiden ja kansallisen politiikan logiikan. Tarkastelen seuraavassa, miten poliittinen neuvottelu näiden kahden logiikan kanssa tapahtuu ja millaista globaalia järjestystä ja globaalin hallinnan rationaliteetteja pääomat ja talous pyrkivät luomaan suhteessa valtioihin, politiikkaan ja demokratiaan.

Lähestyn näitä kysymyksiä analysoimalla kansainvälistä talousjournalismia, erityisesti Financial Times -lehteä, ja sen tuottamia poliittisia rationaliteetteja. FT on luetuin kansainvälinen lehti, joka on suunnattu yhteiskunnan eliiteille, ja sillä on kansainvälisesti näkyvä ja keskeinen asema. Isossa-Britannissa lehti on suosituin liike-elämän johtajille suunnattu päivälehti ja se tavoittaa yli 400000 hyvätuloista "senioriasemassa olevaa kuluttajaa ja päätöksentekijää" (FT 2005b.) Lehti ilmoittaa, että päätöksentekijät lukevat sitä enemmän kuin mitään muuta kansainvälistä 
lehteä Euroopassa. Vuoden 2000 jälkeen tehdyissä Euroopan mielipidejohtajien kartoituksissa FT on ollut laajimmin luettu kansainvälinen päivälehti hallitusten, liike-elämän, median, yliopistojen ja kansainvälisten organisaatioiden päätöksentekijöiden keskuudessa (FT 2005a). Lisäksi lehti on kasvattanut levikkiään voimakkaasti erityisesti Aasiassa (FT 2005b). Lukijakuntansa perusteella FT edustaa siten uuden globaalin hallinnan solmukohtaa ja sitä voi pitää kansainvälisenä tai jopa globaalina julkisena tilana, jossa globaalin hallinnan järjestä ja rationaliteeteista neuvotellaan ja jossa niitä tuotetaan. Pyrin analysoimaan, millaista poliittista rationaliteettia ja logiikkaa $F T$ käyttää tuottaessaan uuden imperialismin teesin mukaista ei-alueellista globaalia järjestystä.

\section{Genealoginen luenta}

Metodisesti analyysi perustuu Michel Foucault'n genealogiseen ajatteluun, jota kiinnostaa erityisesti totuuden ja järjen tuotanto. Kuten Nikolas Rose ehdottaa, on analysoitava totuuden tuottamista - sitä, mitä pidetään järkevänä ja rationaalisena, kuka käyttää järjen ääntä, ja mitkä epistemologiset, institutionaaliset ja tekniset olosuhteet säätelevät ja organisoivat totuuden tuottamista (Rose 1999, 30). Genealogia korostaa myös tiedon tuotannon käytäntöjä. Tarkoituksena on löytää ne moninaiset tietojärjestelmät, jotka kohtaavat ja pyrkivät hallitsemaan toisiaan ja tiedon kenttää. Tietoa pitäisi tutkia toiminnassa: erilaisten vastakkainasettelujen kenttänä, jossa totuuden ja järjen logiikat ja kriteerit risteilevät. Tarkastelun kohteena on, kuinka tälle kentälle muotoutuu poliittinen rationaliteetti, jonka sisällä ja avulla vastakkainasettelut voidaan ratkaista ja järjestää yleisen totuuden tai järjen nimissä (Foucault 1998, 374-386; Rose 1999, 28-30; Clifford 2001, 3). FT:n rationaliteetteja analysoidaankin tässä genealogisella luennalla, joka pyrkii paikantamaan:

(i) Hallitsevat rationaliteetit; käsitteet, teemat ja väitteet: Mitkä ovat tärkeimpiä poliittisia rationaliteetteja ja logiikkoja, useimmin toistettuja käsitteitä, teemoja ja väitteitä, ja miten niitä voi ymmärtää historiallisesti?

(ii) Hallitsevat järjestyksen säännöt: Mitkä ovat tärkeimpiä sääntöjä poliittisten rationaliteettien järjestämisessä? Kuinka eri käsitteiden, teemojen ja väitteiden suhteet määräytyvät ja miten niiden väliset ristiriidat ratkaistaan?

Koska imperiumin rakentamisen keskeisenä dynamiikkana on imperiumin logiikan ja kansallisvaltioiden välinen rajankäynti (ks. myös Harvey 2003, 26-31), tavoitteena on tutkia erityisesti sitä, kuinka kansalliset poliittiset yhteisöt kuvataan. Analysoitavana materiaalina on FT:n kirjoittelu 32 kansallisista parlamenttivaaleista vuodesta 2000 vuoteen 2005. Aineistossa ovat mukana maailman merkittävimmät kansantaloudet: OECD-maat (Italia, Iso-Britannia, Norja, Puola, Tanska, Portugali, Irlanti, Ranska, Tšekin tasavalta, Ruotsi, Slovakia, Saksa, Turkki, Yhdysvallat, Itävalta, Alankomaat, Suomi, Islanti, Kreikka, Espanja, Kanada, Japani ja Uusi-Seelanti) sekä Venäjä, Intia ja Meksiko. Kuudessa maassa järjestettiin kahdet vaalit kyseisellä aikajaksolla, ja molemmat vaalit ovat mukana aineistossa. Aineistossa on 219 juttua, joista 23 on pääkirjoituksia. Jutut kerättiin kutakin vaalipäivää ympäröineeltä kahden viikon ajanjaksolta, ja aineistoon poimittiin kaikki jutut, joissa vaalit ja niiden poliittinen tilanne ovat pääaiheena. ${ }^{1}$

Samalla tavoitteena on ymmärtää rationaliteettien genealogiaa, peilata nykyisiä puhetapoja menneeseen ja yrittää sitä kautta ymmärtää niiden historiallista syn- 
tyä ja risteilyä nykypäivän teksteissä. FT:n historiassa on erityisen kiinnostavaa sen yhteys liberalismiin, finanssipääomiin ja brittiläiseen imperiumiin. Foucault'laisessa ajattelussa liberalismi on modernin hallinnan rationaliteettien keskeinen pohjavirta (Gordon 1991, Rose 1999) ja sen vuoksi on oletettavissa, että brittiliberalismilla on keskeinen rooli lehden eetoksessa.

Toisaalta FT:Ila on pitkät perinteet imperialismin äänenkannattajana. Lehti perustettiin brittiläisen imperiumin loiston päivinä 1880-luvulla palvelemaan kansainvälisten sijoittajien tarpeita kun Lontoon City oli nousemassa maailman finanssikeskukseksi (Kynaston 1988, 1-2). Etusivun iskulauseena oli pitkään ilmoitus siitä, että se oli "laajalevikkisin talouslehti maailmassa" (emt., 61-65). 1800-luvun loppu oli kultakannan aikaa, jolloin maailmantalous oli vähintäänkin yhtä integroitunut kuin 1900-luvun lopussa (Rodrik 1997, 7). Kotimaiset palkat ja hinnat joustivat kullan kansainvälisen hinnan mukaan ja kansallinen autonomia talouspolitiikassa oli kutistettu minimiinsä (Hirst \& Thompson 1996, 44-45). Aika oli, Ronald Robertsonin sanoin, globalisaation take off -vaihetta, joka kesti 1870-luvulta 1920-luvulle (Robertson 1992, 59). Myös kansainvälinen viestintä lisääntyi ja kasvoi nopeasti. Uutisten tuottamisesta ja levityksestä tuli laajamittaista teollista toimintaa, jota vauhdittivat sähkeet ja lennätin (Hamelink 1995, 22). Uutistuotannolla oli selkeät yhteydet kolonialististen siirtomaavaltojen toimintaan. Esimerkiksi uutismarkkinat jyvitettiin uutistoimistojen keskinäisillä sopimuksilla niin, että jokaisella imperiumilla oli oma uutistuotantonsa (Rantanen 1997, 615-617). FT aloitti toimintansa tässä kontekstissa. Sijoittajat, jotka olivat pistäneet rahansa arvopapereihin, rahastoihin ja osakkeisiin Englannissa ja sen siirtomaissa, tarvitsivat tietoa markkinoista sekä koti- että ulkomailla (Kynaston 1988, 4).

2000-luvun alulla on paljon yhteistä 1800-luvun lopun ja 1900-luvun alun take off -vaiheen kanssa. Kun toisen maailmansodan jälkeinen Bretton Woods -järjestelmä purkautui 1970-luvulla, kansalliset valtiot ovat menettäneet autonomiaansa pääomamarkkinoiden ja kaupan vapauduttua (Hirst \& Thompson 1996, 44-45). FT on ollut kehityksen edellä kulkija. Lehti on kansainvälistänyt toimintojaan voimakkaasti koko sodanjälkeisen ajan. Kansainvälistä uutisointia ja kansainvälisten pääomamarkkinoiden seurantaa on vahvistettu voimakkaasti. Lehti mainosti itseään jo 1970-luvulla "Euroopan businesslehtenä". Se alkoi painaa kansainvälistä painosta Frankfurtissa ja ulkomaan kirjeenvaihtajia oli enemmän kuin millään muulla lehdellä New York Timesia lukuun ottamatta. (Kynaston 1988, 375-376, 421-424.) Onkin kiinnostavaa peilata $F T$ :n poliittista rationaliteettia myös historiallisesti: millä tavalla nykyisiä rationaliteetteja voi ymmärtää genealogisesti syntyneinä?

Britti-imperiumin historia ja luonne ovat tietenkin laajojen keskustelujen kohteena, ja olisi hyvin ongelmallista pitää nykyistä $F T$ :a pelkkänä 1800-luvun imperiumin jatkona. Britannian maailmanvalta romahti kultakannasta luopumisen ja siirtomaiden itsenäistymisen myötä (Polanyi [1944] 1971, 23; Arrighi 1978, 75-78; Porter 1996, 368; 2004, 300). Tästä huolimatta britti-imperiumin voi pitää mielessä toisella tavalla - ei niinkään instituutioina vaan enemmänkin hallinnan rationaliteetteina ja kysymyksenasetteluina, jotka ovat ehkä säilyneet ja muuntuneet ajan myötä ja ovat osaltaan tuottamassa nykyisiä hallinnan rationaliteetteja. Peilaankin FT:n rationaliteetteja erityisesti britti-imperiumin toimintatapoja pohtineen tutkimuksen valossa. Käytän hyödykseni Hannah Arendtin (1966) ja Karl Polanyin ([1944] 1971) tulkintoja, joita voi jo pitää klassisina, ja sen lisäksi hyödynnän tuoreempaa tutkimusta 1800 -luvun britti-imperiumin rationaliteeteista (esim. Said 1994; Cain ja Hopkins 1994; Hall 2002; Nasson 2004; Porter 1996; 2004). 


\section{Liberaalit järjet: demokratia ja markkinat}

Locken ja Benthamin klassisen liberalismin peruselementteinä on pidetty rationaalista asennetta yhteiskuntaan, yksinvallan, konservatismin ja perinteiden kritiikkiä, suvaitsevaisuuden ja yksilöllisyyden korostamista sekä rikkumatonta oikeutta sanan- ja mielipiteen vapauteen (Lähteenmäki-Smith 2000; Peters 2005, 14-28). Tämä ei kuitenkaan ole ainoa liberalismi, vaan itse asiassa melkein kaikki modernit poliittiset ideologiat ovat velkaa liberalismille, koska ne pyrkivät vapauttamaan paitsi yksilöitä, myös kansoja (nationalismi, kansalliset vapautusliikkeet), luokkia (sosialismi, kommunismi) tai muita yhteiskunnallisia ryhmiä (vaikkapa naisten vapautusliikkeet). Kuten Colin Gordon (1991, 14-18) on huomauttanut, liberalismia ei tulisi ymmärtää annettuna kokonaisuutena tai yhtenä ideologiana vaan mieluummin historiallisena kysymyksenasetteluna, joka tuottaa erilaisia poliittisia sovellutuksia ja poliittisen hallinnan muotoja, kun sen avulla kritisoidaan yhteiskuntia ja niissä vallitsevia oloja. Foucault'lainen liberalismin ymmärrys kohdistaa huomion liberalismin keskeiseen paradoksiin: on varsin helppoa vaatia vapautta, mutta vaikeaa toteuttaa ja organisoida se käytännössä. Vaikka liberalismi lupaa vapautta, se on myös tuottanut moninaisia modernin poliittisen hallinnan muotoja. Vapauden toteuttaminen tuottaa uusia hallinnan muotoja, joista benthamilainen panoptikon lienee kaikkein kuuluisin esimerkki.

Liberalismin rationaliteetit näyttävät olevan keskeisiä myös FT:n poliittisessa rationaliteetissa, joka näyttää nojautuvan ainakin kahdelle liberalismille: yksilön demokraattisia poliittisia vapauksia korostavalle poliittiselle liberalismille ja markkinoiden vapauttamiseen tähtäävälle taloudelliselle liberalismille.

Poliittinen liberalismi näkyy selvimmin FT:n tavassa korostaa ja ylistää demokratiaa ja sen toimintaa. Demokratian tilaan eri maissa kiinnitetään usein huomiota. Toimivaa demokratiaa ylistetään ja ongelmakohdista ollaan huolestuneita. Maita kuvataan joko demokratioina tai matkalla demokratiaan. Vakiintuneemmissa demokratioissa demokratian tilaa arvioidaan yleensä kiinnittämällä huomiota äänestysvilkkauteen. Italiassa yli 80 prosentin kiipeävä äänestysaktiivisuus noteerataan "suurena päivänä demokratialle Italiassa".2 Alankomaissa kiitellään sitä, että puolueiden vanha ylimielinen tyyli on väistynyt ja tehnyt tilaa demokratialle. ${ }^{3}$ Japanin vaaleja juhlitaan "upeana hetkenä - jonakin, jota japanilainen demokratia on odottanut puoli vuosisataa". ${ }^{4}$ Meksikon vaalien julistetaan "päättävän Meksikon pitkän siirtymisen yhden puolueen hallinnasta pluralistiseen demokratiaan" ja näin Meksikossa "poliittinen täysi-ikäisyys" on astunut markkinatalouden rinnalle..$^{5}$ Intian vaaleja ylistetään "mahtavana ja nöyryyttä herättävänä spektaakkelina, joka herättää oikeutetusti kunnioitusta ympäri maailmaa". ${ }^{6}$ Vastaavasti taas esimerkiksi Venäjän vaaleissa kannetaan huolta vaalien rehellisyydestä ja venäläisen demokratian tilasta. ${ }^{7}$

Demokratian rinnalla $F T$ :n painotus markkinaliberalismiin on näkyvästi esillä voimakkaina vaatimuksina liberaaleista talousreformeista. Rakennereformit tai liberalisointi liittyvät markkinavoimien vapauttamiseen ja valtion ja julkissektorin karsimiseen. Portugali tarvitsee "rankkaa reformia ja tiukkaa otetta julkiseen kulutukseen" ${ }^{8}$ ja Saksalle rakennereformi on "ainoa vaihtoehto". 9 Reformien lista on pitkä: veroreformit, työmarkkinoiden reformi, julkisen sektorin reformi, hyvinvointivaltion reformi, terveys- ja sosiaalisektorin reformi. FT korostaa reformien tarvetta, ja reformi on usein juttujen kehyksenä. Mikä puolue ja kuka poliitikoista kannattaa ja kuka vastustaa reformeja? Voittaako reformipuolue? Voiko voittajista tulla reformaattoreita? ${ }^{10}$ Uuden hallituksen haasteena on usein lista reformeista. ${ }^{11}$ 
Reformipuhetta voi ymmärtää liberalismissa vanhastaan olleella painotuksella muutoksen tarpeesta (Touraine 1990). Tämä ajatus on noussut voimakkaasti esiin erityisesti uusliberaalissa ajattelussa, joka painottaa rakennemuutosten tarvetta. Viimeisten kahdenkymmenen vuoden aikana hyvinvointivaltiota, verojärjestelmiä ja sosiaalipolitiikkaa on vaadittu kovin äänenpainoin reformoitaviksi ja keinoiksi on tarjottu markkinoita, kilpailuttamista, yksityistämistä ja tehostamista (Cameron \& Palan 2004; Christensen \& Lægreid 2002; Clarke 2004; Harvey 2005; Sahlin-Andersson \& Engwal 2002).

FT näyttää kulkevan uusliberaalin reformipuheen kärjessä arvioiden yhteiskuntia taloudellisen uudistumishalun perusteella hyvinkin säännönmukaisesti ja kaavamaisesti. Valtio ja julkissektori ovat reformin tarpeessa ja niiden toimintaa täytyy tehostaa. Tässä mielessä $F T$ myös jatkaa omaa poliittista linjaansa, jonka se omaksui heti toisen maailmansodan jälkeen, kun hyvinvointivaltion käsite syntyi Englannissa sotavaltion (warfare state) jatkeeksi. Myös sille FT auttoi heti tuottamaan kriittisen rationaliteetin. Vuonna 1949 lehti muotoili "tosiasiat kuivina faktoina" tapaan, joka muistuttaa paljon nykyisiä poliittisia puhetapoja: "Kukaan ei ehdota, että hyvinvointivaltio pitäisi purkaa... mutta on niitä, jotka uskovat, että ellei koneistoa ohjata paljon tiukemmin ja ottaen huomioon tiukentuneet olosuhteet, hyvinvointivaltion perustukset tulevat välttämättä sortumaan ja tuhoutumaan" (Kynaston 1988, 189).

Lehti kritisoi "joulupukkivaltiota" ja vaati esimerkiksi 1952 julkisen kulutuksen leikkauksia, koska "meillä on hyvin vähän aikaa jäljellä, jos haluamme välttää romahduksen, jonka vaikutuksista tämä maa ei ehkä koskaan toipuisi" (Kynaston 1988 , 228). Samantapainen valtiokriittinen liberalismi näyttää voivan hyvin nykyisessä $F T$ :ssa, jonka poliittisen järjen mukaan valtio ja julkissektori ovat lähes maasta riippumatta uppoamistilassa ja vaativat nopeita toimia.

\section{Markkinoiden ja demokratian törmäyspisteissä}

Genealogisen analyysin yhtenä pääajatuksena on etsiä ristiriitaisuuksia ja moninaisuutta. Mitkä ristiriitaiset logiikat ja toden ja rationaalisen logiikat ja kriteerit teksteissä nousevat esiin? (Rose 1999, 29.) Foucault lainaa Nietzschen ajatusta historian tutkimuksesta, joka "tekee onnelliseksi", koska se auttaa havaitsemaan, ettei "omista yhtä kuolematonta, vaan monta kuolevaista sielua". Historiaa tutkimalla ei etsitä yhtä unohdettua identiteettiä, vaan monimutkaista järjestelmää, jota ei voi hallita yhdellä synteesillä. (Foucault 1998, 386.) Tarkoituksena on siis selvittää, mitkä moninaiset rationaliteetit, järjet ja logiikat törmäävät toisiinsa, ovat päällekkäisiä ja pyrkivät hallitsemaan toisiansa.

FT:n tapauksessa rationaliteettien ristiriitaisuus näkyy ehkä selvimmin silloin, kun poliittisen ja taloudellisen liberalismin rationaliteetit joutuvat törmäyskurssille ja niiden tulokset ovat ristiriidassa keskenään. Markkinatalous ja demokratia tuottavat kumpikin omalla logiikallaan erilaiset kriteerit vaalien ja niiden tulosten arviointiin. Vaaleissa, joissa liberaaleja talousreformeja kannattavat puolueet voittavat, ongelmia ei juuri synny. Esimerkiksi Slovakia saa kiitosta siitä, että rankkojen talousreformien kannattajat voittavat vaaleissa, mitä yleensä ei ole tapahtunut postkommunistisissa maissa: "Ulkomaiset sijoittajat ja pääomamarkkinat toivottavat uuden hallituksen tervetulleeksi. Se tulee olemaan yhtenäisempi kuin nykyinen hajanainen vasemmisto-keskusta-koalitio." 12

Kun markkinareformien kannattajat häviävät vaaleissa, FT:n jutuissa joudutaan järjestämään poliittisen ja taloudellisen liberalismin ristiriitaisuuksia. Miten kirjoit- 
taa demokratiasta, jossa talousreformi ei saa kannatusta? Näyttää siltä, että näissä kahden logiikan törmäyspisteissä $F T$ on kehittänyt joukon tapoja, joilla markkinoiden ja demokratian ristiriitaisuudet ratkaistaan edellisen hyväksi. Yleisimpiä tapoja ovat talouden ongelmien esittäminen ensisijaisena, politiikan ja äänestäjien järjen kyseenalaistaminen sekä vahvojen johtajien merkityksen korostaminen.

Yleisin tapa järjestää talouden ja demokratian suhde on esittää talousreformi kyseenalaistamattomana ja väistämättömänä tehtävänä, joka politiikan pitää joka tapauksessa tehdä. Tämä "tehtävänanto" politiikalle on selkeästi esillä sekä uutisjutuissa että pääkirjoituksissa. FT:Ila näyttää olevan selkeä käsitys "oikeasta" politiikasta ja siitä, mitä kyseisessä maassa tulisi tehdä - vaalituloksesta huolimatta. Esimerkiksi Intian tapauksessa reformin kannattajien häviötä tulkitaan seuraavasti: "Lyhyellä tähtäimellä eilisten vaalien ehdoton tuomio voi saada Intian talousreformin kannattajat harkitsemaan uudelleen. Mutta kun šokki on sulatettu, johtopäätös voi yhä hyvin kallistua vielä laajemman taloudellisen reformin puolelle."13

Myös Ruotsille suositellaan julkisten palvelujen virtaviivaistamista, vaikka julkisten palvelujen säilyttämistä edustava puolue on juuri voittanut vaaleissa. ${ }^{14}$ Tšekin hallitusta opastetaan talouskuriin siitä huolimatta, että vaaleissa on juuri voittanut hyvinvointipalveluita korostanut puolue. ${ }^{15}$ Saksan uutta hallitusta varoitetaan siitä, että sen on pidettävä talousreformit ohjelmansa kärjessä huolimatta vaalituloksesta. ${ }^{16}$ Sellainen vaalitulos, joka ei ole FT:n oman reformiohjelman mukainen, syrjäytyy lehden retoriikassa välttämättömien ja joka tapauksessa tarvittavien reformien alle. Äänestäjien tahdolla ei juuri tunnu olevan painoarvoa, mikäli se ei ole lehden tahdon mukainen.

Kansallinen politiikka kuvataan usein talouden välttämättömyyksien rinnalla kielteisessä valossa. Japanissa "leijonansydäminen" pääministeri taistelee "poliittista koneistoa"17 ja "kakunjakopolitiikkaa"18 vastaan. Meksikoa vaivaavat "oligopolistit" ja "erityiset"19, Saksaa taas "aataminaikaiset"20, intressiryhmät. Politiikkaa syytetään lehmänkaupoista ${ }^{21}$ ja "ideologisista siksakeista"22. Tässä puhetavassa on näkyvissä myös se, kuinka kansainvälistyvä talous haastaa omalla rationaliteetillaan kansallisen poliittisen yhteisön. Sodan jälkeinen kasvupolitiikka perustui monissa valtioissa valtion vahvalle roolille, devalvaatioille ja kansallisten hyvinvointijärjestelmien rakentamiselle. Kansainvälistyvien markkinoiden ja pääomien tapana on nähdä kansallinen politiikka vanhentuneeksi ja "likaiseksi" ja kansallisen politiikan valtarakenteet kielteisiksi, koska ne muodostavat usein kansallisia valtakeskittymiä, jotka myös suojaavat kansallisia talouksia ja ovat näin esteenä markkinoiden kansainvälistymiselle.

Toinen tapa, jolla "väärää" vaalitulosta järjestetään ja rationalisoidaan, on äänestäjien motiivien ja järjen kyseenalaistaminen. Äänestäjiä kuvataan tunteiden ja vaistojen viemiksi. He ovat "vihaisia"23, "muutosta vastaan"24, "vaistomaisesti reformeja vältteleviä" ja "hätääntyneitä"25, "kostavat"26, "tuulettavat vihaansa",,27 "pilalle hemmoteltuja"28, heidän "pelkojansa käytetään hyväksi"29, ja kuten ranskalaisten tapauksessa, he tuntevat "pinnallista epäluuloa" globaalia kapitalismia kohtaan..$^{30}$ Usein poliittiset ongelmat kehystetään irrationaaliseksi populismiksi ja nationalismiksi. Populismin ${ }^{31}$ ja kovapäisen nationalismin ${ }^{32}$ lisäksi ongelmana mainitaan muukalaisviha ainakin Italian, Tanskan, Ruotsin, Venäjän, Itävallan, Turkin ja Intian poliittisessa elämässä. ${ }^{33}$

Monissa tapauksissa äänestäjät ja demokratia nähdään vastakkaisiksi talousreformin vaateille. Esimerkiksi Venäjällä Putinin "suurin ongelma on se, että modernisaation täytyy edetä vaiheeseen, jossa reformit todella tekevät kipeää" ${ }^{34}$, tai USA:n vaaleissa ongelmana on se, että talouden todellisista ongelmista ei voi keskustella vaaleissa, koska ratkaisut köyhdyttäisivät amerikkalaisia, ja se on 
"demokraattisen prosessin ongelma". ${ }^{35}$ Saksassa "kukaan ei epäile, että Saksa tarvitsee radikaalia talousreformia", mutta sen esteenä on "oikean" reformipolitiikan suuri ongelma:

"Saksassa vaaleja ei voi voittaa, jos lupaa liikaa reformeja, ei vaikka kaikki puoluejohtajat tietävät, että eläkkeet, terveyspalvelut, työmarkkinat ja verotus tarvitsevat radikaalia toimintaa." ${ }^{36}$ Äänestäjät kuvataan lohduttomalla tavalla kykenemättömiksi ymmärtämään, mistä politiikassa todella on kysymys: järkevä politiikka jää järjettömän äänestäjän panttivangiksi.

Kun vaalit, politiikka ja äänestäjät tuottavat ongelmia talouden reformaattoreille, niin apuun huudetaan usein vahvaa johtajaa, joka ajaisi reformit läpi vastustuksesta huolimatta. Sellainen on esimerkiksi Japanin uudistusmielinen pääministeri: "Junichiro Koizumi on johtaja, jota markkinat rakastavat. Hänellä on takanaan julkinen tuki ja mandaatti reformien toteuttamiseen. Japanin pörssi lisäsi eilen äänensä hänen voittoonsa, nousten korkeammalle kuin neljään vuoteen." ${ }^{37}$

Päinvastaisessa tapauksessa reformin kannattajien häviö Puolassa tulkitaan niin, että maa on jäänyt poliittisen epävarmuuden armoille juuri kun se olisi tarvinnut vahvaa johtajuutta. ${ }^{38}$ Myös Saksa kärsii johtajuuden puutteesta: "Saksa tarvitsee kanslerin, joka on julma, rohkea ja luja - ja halukas hyökkäämään suurpääoman etuja vastaan yhteisen hyvän vuoksi." ${ }^{39}$ Ongelmana ovat nimenomaan kansallisen pääomat, joiden nähdään yhdessä ammattiliikkeen kanssa sementoineen kansallisen järjestelmän reformeja vastaan.

\section{Uutta imperialismia?}

Entäpä sitten imperialismi? Miten FT:n poliittiset rationaliteetit pitäisi ymmärtää imperialismin kontekstissa tai peräti uuden imperialismin muotona?

Markkinaliberalismi ja markkinoiden vapauttaminen ovat keskeisimpiä $F T: n$ poliittisista rationaliteeteista ja tässä muodossa $F T$ edustaa ennen muuta ekonomismia: vahvaa uskoa siihen, että sosiaaliset ja poliittiset ongelmat voidaan hoitaa taloudellisilla ratkaisuilla (Taylor 2004, 171). FT:n keskeinen poliittinen rationaliteetti rakentuu talousreformille ja painottaa sen ensisijaisuutta ja välttämättömyyttä, Tämän ajattelun juuret nivoutuvat puolestaan poliittisen taloustieteeseen ja sen rationaliteetteihin (Foucault 2000, 207; Hindess 1998, 213-223, Taylor 2004, 69-82; Rose 1999, 33-39; Polanyi [1944] 1971, 40).

Poliittinen taloustiede ja markkinaliberalismi olivat keskeisiä myös 1800-luvun brittiläisessä imperialismissa. Lontoon Cityllä ja sijoittajilla oli keskeinen merkitys imperiumin rakentamisessa (Porter 2004, 31, 258). Tätä tulkintaa ovat edustaneet nykykeskustelussa erityisesti Peter J. Cain ja Anthony G. Hopkins, jotka näkivät britti-imperiumin perustuvan Cityn vetämälle "herrasmieskapitalismille" (Cain \& Hopkins 1986; Dumett 1999).

Myös Hannah Arendt painotti, että britti-imperiumin laajentumispyrkimykset perustuivat kapitalisteille, jotka etsivät uusia sijoitusmahdollisuuksia. Kun "vanhoissa" imperiumeissa valloitukset tehtiin sotavoimilla, niin uudessa imperialismissa keskeisessä roolissa oli liiketoiminta ja sen jatkuva laajentaminen, uusien raaka-aineiden, työvoiman ja markkinoiden etsintä. Arendt lainaa Cecil Rhodesia, joka vaati brittejä "heräämään siihen tosiasiaan, että on mahdotonta selviytyä, ellei hallitse maailmankauppaa" ja "että sinun elinkeinosi on maailma ja sinun elämäsi on maailmalla eikä Englannissa". (Arendt 1966, 125, 132.)

Karl Polanyi puolestaan pohti talouden ja imperialismin suhdetta niin sanotussa sadan vuoden rauhassa 1814-1915, jolloin Krimin sotaa lukuun ottamatta Ranska, Preussi, Itävalta, Italia ja Venäjä olivat sodissa toisiaan vastaan vain kahdeksantois- 
ta kuukautta. Polanyin ([1944] 1971, 3-20) mielestä tämä "pragmaattisen pasifismin voitto" liittyi kansainvälisen liike- ja pankkitoiminnan etuihin. Kansainvälinen pankkitoiminta, haute finance, kehittyi instituutioksi, joka oli riippumaton yksittäisistä valtioista ja hallituksista. Kansainväliset sijoittajat rahoittivat teollisuutta, julkisrakentamista ja pankkeja sekä yksityisellä että julkisella sektorilla. Siksi niiden päätavoitteena oli välttää suursota, ja pankkiirit käyttivät valtaansa pitääkseen valtiot ojennuksessa. Pieniä sotia ja siirtomaiden järjestyksenpitoa sallittiin, mutta suursota olisi romauttanut koko kansainvälisen talousjärjestelmän, joten sitä piti välttää. Tämä tiukan pragmaattinen järjestelmä takasi suuren rauhan kauden ja salli pienet konfliktit. Siten "melkein jokainen sota oli sijoittajien organisoima; mutta myös rauha oli heidän organisoimansa" (Polanyi [1944] 1971, 16).

Myös $F T$ näyttää edustavan nimenomaan demokratian suhteen pragmaattista rationaliteettia samaan tapaan kuin Arendt ja Polanyi kuvaavat aikaisempaa imperialismia. Länsimainen demokratia kelpaa, jos se avaa uusia rauhanomaisia paikkoja markkinataloudelle ja sijoittajille. Demokratia ihanteineen ja hyveineen kelpaa legitimoimaan markkinataloutta ja tuottaa sille suotuisat poliittiset olosuhteet, mutta silloin kun liberaalit demokratiat eivät valitse markkinareformeja, demokratia ja sen tulokset kyseenalaistetaan moraalisesti epäilyttävinä ja epärationaalisten tunteiden hallitsemina.

Tätä taustaa vasten on ymmärrettävää, että kansainvälinen talousjournalismi ei ole suoraan sitoutunut brittiläiseen imperialismiin, vaan useimmiten lehden näkökulmaa voi ymmärtää jos ajattelee sijoittajaa, joka pohtii sijoitusmahdollisuuksiaan. Näin monissa tapauksessa vakiintunut järjestelmä on ensisijainen toive ja poliittiset levottomuudet pahiten pelätty hankaluus. Näin voi ymmärtää myös $F T$ :n vaaliaineiston rationaliteetteja. Eri maille suositellaan reformeja, jotka avaisivat kansantaloutta sijoittajille ja markkinoiden toiminnalle ja vähentäisivät valtion, kansallisen politiikan ja julkisen sektorin merkitystä. FT pyrkii järjestämään maailmaa sijoittajan ja kansainvälisen pääoman silmin, koska se uskoo, että talouden avautuminen tuottaa tehokkaamman talouden ja vakaamman yhteiskunnan.

Demokratia on hyvän yhteiskunnan itseisarvo, jota FT kannattaa ja josta se on huolissaan. Toisaalta demokratia jää kuitenkin toissijaiseksi, jos se asettuu valtion puolelle ja markkinoiden avaamisen tielle. Näin FT tulee suosittaneeksi epädemokraattista järjestelmää. Tämä ristiriita oli olemassa jo 1800-luvun brittiläisessä imperiumissa. Bernard Porter $(1996,370)$ huomauttaa, että yksi imperiumin keskeinen ristiriita oli imperiumin ja libertaksen välinen: miten britit saattoivat sovittaa yhteen kotoisen liberalisminsa ja ne selvästi autoritaariset piirteet, joiden varaan he rakensivat hallintajärjestelmiä ulkomailla? Brittien käytös oli janus-kasvoista: toisaalta brutaalia ja ankaraa järjestyksenpitoa, toisaalta hyväntahtoista (Nasson 2004, 206-207). Myös talousreformeissa näkyi sama ristiriitaisuus. Esimerkiksi Intiassa markkinaliberalismin juhlavat aatteet pyhittivät samalla myös brittiteollisuuden edut eivätkä sallineet paikallisen teollisuuden tukemista tulleilla, tariffeilla, tukitoimilla tai valtionyrityksillä. Sen sijaan kolonialistit rakensivat teitä ja siltoja, jotka auttoivat kytkemään maan maailmantalouteen - tosin tietenkin brittivetoisesti kytkemällä Intian emämaan raaka-aineiden tuottajaksi. (Porter 1996, 4.)

Keskeisenä juonteena oli brittien johtoaseman korostaminen. Vaikka se esiintyi usein eksplikoidusti hyväntahtoisena lähetystehtävän toteuttamisena, se merkitsi myös autoritaarisuutta, kolonialistisen "toisen" tuottamista (Said 1994), joka toimi tekemällä eron "sivistyneen" ja "villin" välille (Hall 2002; Harvey 2005, 2) ja rohkaisi brittejä näkemään itsensä mallina muille (Nasson 2004). Autoritaarisuus tuli esiin myös johtajuuden ja reformien isällisessä korostamisessa. Britit näkivät itsensä johtajiksi, joiden tehtävänä oli modernisoida ja reformoida siirtomaat. Esimerkiksi viktoriaanit vertasivat mielellään Intian modernisoimista Rooman valtakunnan 
saavutuksiin Euroopassa. (Porter 1996, 21, 34-35, 41-44, 79-80, 130-140.) Samaan aikaan briteillä oli suuria epäilyksiä siirtomaiden kansojen poliittisista kyvyistä: "Parhaimmillaan ajateltiin, että he eivät ole vielä kypsiä parlamentaariseen itsehallintoon, pahimmillaan heitä ei pidetty siihen lainkaan kyvykkäinä" (emt. 19).

Nämä 1800-luvun britti-imperialismin piirteet näyttävät olevan ainakin jossain muodossa mukana myös nykypäivän FT:ssa. Vahvan johtajan korostaminen tuntuu varsin vieraalta klassisen liberalismin näkökulmasta, mutta näyttää olevan osa uusliberaalia ajattelua, joka on flirttaillut poliittisesti autoritaarisuuden kanssa. Kuten David Harvey on uusliberaalin ajattelun historiassaan huomauttanut, uusliberaalia ohjelmaa ovat toteuttaneet vahvat poliittiset johtajat, ja markkinaperustaisia uudistuksia on ajettu läpi myös autoritaarisissa järjestelmissä, kuten Chilessä tai Kiinassa (Harvey 2005). Markkinaliberalismi ja poliittinen liberalismi eivät näin välttämättä kulje käsi kädessä toisiaan tukien. Ainakin FT suosii selkeästi markkinaliberalismia ja johtajuutta ja kyseenalaistaa kansojen ja kansalaisten kyvyn päättää itseään koskevista asioista. FT:n poliittiset rationaliteetit kaiuttavat näin vanhoja britti-imperialismin rationaliteetteja ja samalla myös toistavat niitä ristiriitaisuuksia, joista 1800-luvun britti-imperiumi kärsi.

Foucault'laisessa hallinnan analyysissa valtion tärkein huolenaihe on sen turvallisuus: kuinka valtio voidaan organisoida tavalla, joka takaa sen jatkuvuuden? Tämä on myös markkinaliberalismiin perustuvissa valtioissa keskeinen huoli ja hallinnan peruste. Markkinaliberaalissa valtiossa turvallisuus yhdistyy vaurauteen ja sitä tuotetaan kahdella tavalla: luomalla markkinoiden kautta vaurautta sekä hallittavien osallistumisella parlamentin kautta (Gordon 1991, 19). Kun nämä kaksi ovat ristiriidassa, demokratia väistyy, ja siten talouden ylivalta voidaan nähdä rationaliteetiksi, joka pitää taloutta valtion turvallisuuden kulmakivenä.

Tässä mielessä FT:n poliittista rationaliteettia voi myös pitää vallankumouksellisena siinä mielessä, että se pyrkii muuttamaan yhteiskuntia. Reformit ja vallankumoukset ovat sukulaisaatteita ja molemmat kuuluvat modernin politiikan järjen ytimeen (Taylor 2004, 176). Taistelu vanhaa valtaa, ancient régimeä, vastaan on ollut modernin poliittisen toiminnan keskeinen ajatus 1700-luvulta lähtien sekä länsimaissa että kommunistissa vallankumouksissa. Kuten Alan Touraine huomauttaa, vallankumouksellisia yhdistää ajatus siitä, että he alistavat ja järjestävät koko sosiaalisen elämän yhden keskeisen periaatteen alle, joka sitten määritellään järkeväksi ja luonnolliseksi. Yhteiskunnan voi sen jälkeen kuvata tämän yhden universaalin prinsiipin mukaan. Tämä ajattelutapa on elänyt selvästi myös markkinaliberalismissa, joka luottaa markkinatalouden luonnollisuuteen ja lakeihin. Modernille kapitalismille on tyypillistä se, että talous ja taloudelliset toimijat irrotetaan yhteiskunnallisesta kontekstistaan. Taloudelliset subjektit erotetaan juuristaan ja heidän rationaalinen toimintalogiikkansa asetetaan vastakkain mahdollisten vastustajien kanssa: naisten ja lasten, vaistojen ja intohimojen, korporativismin suojissa piileskelevien laiskojen työntekijöiden ja tietämättömien ja pahantahtoisten kolonialistien. (Touraine 1990, 122-132.) Samaan tapaan myös FT käyttää läntistä universaalin talousjärjen ääntä, joka heitetään kansallisen korporatiivisen politiikan ja tietämättömien ja tunteikkaiden äänestäjien päälle.

\section{Globaalin hallinnan tilat}

FT muodostaa kansainvälistyneen julkisen tilan, joka ei ole sidoksissa demokraattisiin rakenteisiin, ja on esimerkki globaalin talouden tiloista, jotka erkanevat kansallisesta politiikasta ja demokratiasta. Pikemminkin se näyttää muodostavan yhden globaalin hallinnan solmukohdan, joka järjestää valtioita ja politiikkaa kan- 
sainvälisen talouden rationaliteeteilla. Samalla FT näyttää tuottavan ei-alueellisen poliittisen järjen, joka ei ole suoraan tai institutionaalisesti sitoutunut mihinkään suurvaltaan, vaan ottaa mieluummin lähtökohdakseen talousreformin ja sen välttämättömyyden kaikissa maissa. Tällä äänellä ei siis tunnu olevan selkeää isänmaata, ei komentokeskusta, ja sen vaateita voidaan soveltaa missä tahansa niin kauan kuin pidetään kiinni sitä ohjaavista markkina-ajattelun maksiimeista. Ainakin tässä mielessä näitä rationaliteetteja voi pitää niin sanotun uuden imperialismin rationaliteetin muotoina; esimerkkinä uudesta imperiumista, jota eivät rakenna niinkään armeijat, vaan paremminkin pienet mustat kirjaimet vaaleanpunaisella paperilla rakentaen vapauden ja demokratian nimissä valtiota purkavaa talousjärjestystä.

FT:n ja muiden kansainvälisten julkisten tilojen kohdalla tarvittaisiin kuitenkin lisää tutkimusta niiden roolista ja merkityksestä. Harvey $(2003,26-31)$ pitää keskeisenä tutkimuskohteena sitä, kuinka rahan ja politiikan logiikat eroavat toisistaan. Pääomat toimivat omalla logiikallaan etsien sijoitusmahdollisuuksia yli valtiollisten rajojen, eikä niiden toiminta ole sidottu poliittisen päätöksenteon rakenteisiin ja instituutioihin. Samaan aikaan valtioiden logiikkana on toimia omalla alueellaan ja tehdä poliittisia päätöksiä koskien oman alueensa tulevaisuutta. Pääomat toimivat jatkuvassa tilassa ja ajassa, kun taas politiikka toimii alueellisesti rajatussa tilassa ja demokratioissa myös ajallisesti rajatussa vaalien syklissä. Näiden kahden logiikan välissä toimii kuitenkin, kuten Harvey huomauttaa, suuri joukko erilaisia välittäviä instituutioita ja prosesseja, jotka liittyvät rahapolitiikkaan, kansainvälisiin finanssiinstituutioihin ja valtioiden talouspolitiikkaan (emt. 133). Syntyy instituutioita, käytäntöjä ja tiloja, joissa kansallisia talouksia ja yhteiskuntia kuvataan ja arvioidaan.

Kansainvälisiä julkisia tiloja voi ajatella tästä näkökulmasta välittävinä tiloina, joissa pääomien ja valtioiden välisestä suhteesta neuvotellaan. Ainakin hypoteesina voi esittää, että on muotoutunut ja muotoutumassa myös kansainvälisiä julkisia tiloja, joissa tuotetaan globaaleiksi pyrkiviä poliittisia rationaliteetteja. Kiinnostavaa on se, missä nämä tilat ovat, millaisia ne ovat ja mihin niissä tuotetut poliittiset hallinnan muodot ja poliittiset järjet perustuvat? Mikä on esimerkiksi kansainvälisesti leviävän länsimaisen valtamedian rooli ja millaista poliittista järkeä se käyttää kuvatessaan ja arvioidessaan politiikkaa ja poliittisia yhteisöjä? Toisaalta pitäisi tutkia, miten kansainvälisesti tuotettu poliittinen järki siirtyy kansalliselle tasolle. Mitä hierarkioita muodostuu globaalien ja kansallisten medioiden välille: miten globaalien tilojen teemat siirtyvät kansallisiin medioihin? Kiinnostavaa on myös vastarinnan tutkimus: missä ovat vastajärjet ja miten ne nousevat esiin? Myös kansainvälisiä julkisia tiloja pitäisi tutkia suhteessa poliittiseen päätöksentekoon ja eliitteihin. Mikä on kansainvälisten julkisten tilojen merkitys poliittisessa päätöksenteossa? Miten päätöksentekijät ja eliitit käyttävät niitä?

Tällaisten kysymysten tuottamisessa ei-alueellisen "uuden" imperialismin teoriaa voi käyttää hyvin taustahypoteesina, koska se tarjoaa yhden tavan ymmärtää kansainvälisten julkisten tilojen roolia suhteessa vallankäyttöön. Globalisaatioteorioihin verrattuna imperialismin käsite tavoittaa paremmin valtadynamiikan ja tuo sen julkisten tilojen tutkimukseen.

Samalla kysymys nykyisen imperiumin luonteesta jää kuitenkin vielä hyvin avoimeksi. Tutkimuksen tarvetta lisää ennen muuta se, että on ehkä epärealistista kuvitella, että julkisia tiloja voisi hallita yksi imperialistinen rationaliteetti. Marxilaisen teorian kokemista kolhuista voisi oppia sen, että teorialla ei kannata tuottaa liian kaavamaista kuvaa yhteiskunnan mekanismeista ilman historiallisen tilanteen tutkimusta. Näyttää esimerkiksi siltä, että marxilaisen teorian edustajat kuten Giovanni Arrighi, Samir Amin ja David Harvey ovat kaikki valmiita myöntämään sen, että marxilaisella luokkataistelulla ja luokan käsitteellä ei voi selittää imperialismin saaman vastarinnan ja nykyisten poliittisten identiteettien ja kamppailujen muo- 
toja ja että teoria on epäonnistunut erilaisten identiteettien vähättelyssä (Arrighi 2003; Harvey 2005, 171-180).

Imperialismin muotoja ja rationaliteetteja tutkiessa onkin hyvä ottaa vakavasti historiallinen tilanne ja sen erityispiirteiden ymmärtäminen sen sijaan, että ottaisi lähtökohdaksi kaiken kattavan teorian, joka jo valmiiksi sisältää käsityksen imperialismin lähtökohdista ja toteutumistavoista. Todennäköisempää on, että myös julkisissa tiloissa risteilee monenlaista poliittista järkeä ja logiikkaa, joilla on omat erityiset genealogiansa.

"Alle Grossmächte sind imperialistisch", lausahti presidentti Paasikivi vuonna 1940 ja lisäsi, että Suomikin olisi sellainen, jos se olisi tarpeeksi suuri. Paasikiveä lainaa Bernard Porter, joka haluaa tuoda esiin imperiumin rakentamisen perusdynamiikan. Kun jonkin valtion talous alkaa vaatia ulkomaisia raaka-aineita, suurvallan täytyy tukahduttaa sisäisiä konfliktejaan tai hallita ulkoisia uhkia, niin se ryhtyy rakentamaan imperiumia. Ei kuitenkaan ole olemassa yhtä "imperialistista" rationaliteettia tai puhetapaa, joka aina liittyisi imperialismiin. Porterin $(2004,310)$ sanoin "melkein mikä tahansa puhetapa kelpaa": keskiluokkainen edistys tai paternalismi; rodullinen ylimielisyys tai avarakatseinen suvaitsevaisuus; rationaalinen valistus tai konservatismi; natsi-Saksan pahat aikeet tai nykyisen USA:n hyvät aikeet. Tutkimuksen tehtäväksi jää selvittää näiden sanojen suhdetta muihin yhteiskunnan rakenteisiin ja yrittää ymmärtää, miten kunkin ajan imperialismit yrittävät omassa historiallisessa tilanteessaan valtansa rakentaa ja oikeuttaa.

\section{Viitteet}

1 Jutut haettiin Financial Timesin sähköisestä FT.com -arkistosta. Aineistoon otettiin jutut, jotka oli julkaistu lehden paperiversioissa. Koska tarkoituksena oli keskittyä nimenomaan FT:n omiin rationaliteetteihin, mukaan ei otettu niitä juttuja, jotka oli kirjoittanut lehden ulkopuolinen asiantuntija tai kommentaattori. Yksityiskohtaisempi empiirinen analyysi ilmestyy artikkelissa Kantola (2006).

2 World News - Europe: Red faces in ministry over fiasco at the poll booths: High turnout reflected the strong popular interest in the election, but caught the organisers on the hop, Paul Betts, May 14, 2001.

3 Leader: Return to the centre, January 24, 2003.

4 Postal vote: Koizumi makes Japan choose between paternalism and the free market, David Pilling, August 10, 2005.

5 Comment \& analysis: Fox spurs a revolution: The former Coca-Cola salesman's victory marks Mexico's transition from one-party rule to pluralist democracy, Henry Tricks and Richard Lapper, July 04, 2000.

6 Leader: Indian vote signals, May 03, 2004

7 Europe: Putin holds political cards after opponents trounced, By Andrew Jack and Arkady Ostrovsky, December 09, 2003. Leader: Putin power, December 09,2003.

8 Europe: Portuguese PM faces tough route to 'Nordic' prosperity, Peter Wise in Lisbon; Feb 22, 2005.

9 Leader: Time for leadership in Germany, September 24, 2002.

10 Europe: Triumph brings Persson closer to euro, Christopher Brown-Humes and Nicholas George in Stockholm; September 17, 2002. Comment \& analysis: Germany resists change, but Joschka Fischer looks ahead. Brian Groom and Haig Simonian; September 24, 2002. German elections: Schröder promises to 'push forward with renewal', Hugh Williamson in Berlin; September 24, 2002. Comment \& analysis: Free trade with the US and Canada did not spur wider economic reform, and limited progress towards creating prosperity is in danger, John Authers and Sara Silver; July 01, 2003.

11 Europe: Czechs' modest new premier faces up to huge reform challenge. Robert Anderson; June 19, 2002. 
12 Europe: Centre-right poll win boosts Slovakia's EU chances, Robert Anderson in Bratislava, September 23, 2002

13 Asia-Pacific: Voters take revenge on India's leading symbol of reform, Edward Luce, May 12, 2004.

14 Leader: Same Swedes, September 17, 2002.

15 Leader: Czech chance, June 17, 2002

16 German elections: Business gloomy on growth prospects, By Bertrand Benoit in Berlin, September 24, 2002.

17 Koizumi vindicated: renewal is achieved for his party and is in prospect for Japan, David Pilling, September 132005.

18 Koizumi vindicated: renewal is achieved for his party and is in prospect for Japan, David Pilling, September 13, 2005.

19 Comment \& analysis: Fox spurs a revolution: The former Coca-Cola salesman's victory marks Mexico's transition from one-party rule to pluralist democracy, Henry Tricks and Richard Lapper, July 04, 2000.

20 Inside track: Colours of coalition, Daniel Bogler, September 27, 2002.

21 Lex Column: German gridlock, September 19, 2005.

22 Leader: Germany votes, September 20, 2002.

23 Leader: Czech chance, June 17, 2002.

24 Political gridlock in Germany reflects a vote against change, Wolfgang Munchau, September 202005.

25 Radical reform alarms German voters, September 15, 2005.

26 Asia-Pacific: Voters take revenge on India's leading symbol of reform, Edward Luce, May 12, 2004.

27 Leader: Poll Shock, September 25, 2001.

28 World News - Europe: Norwegian electorate set to abandon party loyalties: There is uncertainty about which will emerge as biggest party, Christopher Brown-Humes and Valeria Criscione, September 06, 2001.

29 Radical Reform alarms German voters, September 15, 2005.

30 Comment \& Analysis: France goes on sale, Victor Mallet, June 18, 2002.

31 Centre-left wins majority in Norwegian election, Päivi Munter in Oslo, September 122005.

32 Leader: Bush gets mandate to be strong abroad, November 04, 2004.

33 Comment \& Analysis: Hail Berlusconi: The scale of the centre-right's victory suggests Italy's new premier has a mandate for change but he faces difficulties on at least three fronts, James Blitz, May 15, 2001. Leader: Rasmussen twins, November 22, 2001. Leader: Same Swedes, September 17, 2002. Europe: Leaders fall on swords as voters rise in rebellion, Leyla Boulton, November 05, 2002. Europe: Prospect of Haider comeback looms over coalition politics, Eric Frey in Vienna, November 26, 2002. Leader: Putin power, December 09, 2003. Leader: Indian vote signals, May 03, 2004.

34 Comment \& analysis: Four more years: but will Putin's desire for a strong state hamper economic reform?: Top jobs set an assertive tone; Andrew Jack and Stefan Wagstyl, Mar 17, 2004.

35 FT Money: The morning after, and a nation beset by debts, Philip Coggan, November 06, 2004.

36 Radical reform alarms German voters, September 15, 2005.

37 Lex Column: Enemy of the state, September 13, 2005.

38 Leader: Poll shock, September 25, 2001.

39 Leader: Time for leadership in Germany. September 24, 2002. 


\section{Kirjallisuus}

Arendt, Hannah (1966)

The Origins of Totalitarianism. New Edition. New York: Harcourt.

Arrighi, Giovanni (1978)

The Geometry of Imperialism. London: New Left Books.

Arrighi, Giovanni (2003)

Lineages of Empire. Teoksessa Balakrishnan, Gopal (ed.) Debating Empire, 29-42. London: Verso.

Bacevitch, Andrew J. (2004)

American Empire: The Realities and Consequences of U.S. Diplomacy. Cambridge: Harvard University Press.

Balakrishnan, Gopal (ed.) (2003)

Debating Empire. London: Verso.

Cain, Peter J. \& Anthony G. Hopkins (1994)

British Imperialism: Innovation and Expansion 1688-1914. New York: Longman.

Cameron, Angus \& Ronen Palan (2004)

The imagined economies of globalisation. London: Sage.

Christensen, Tom \& Per Lægreid (2002)

New Public Management: The transformation of ideas and practise. Aldershot: Ashgate.

Clarke, John (2004) Changing Welfare, Changing State. New Directions in Social Policy. London: Sage.

Clifford, Michael (2001) Political genealogy after Foucault: Savage Identities. New York: Routledge.

Dumett, Raymond (1999) Gentlemanly Capitalism and British Imperialism. The New Debate on Empire. New York: Longman.

Ferguson, Niall (2005) Colossus: The Rise and Fall off the American Empire. London: Penguin Books.

Foucault, Michel (1998) Nietzsche, Genealogy, History. Teoksessa Aesthetics, Method and Epistemology. Essential Works of Foucault 1954-1984. Volume Two, 369-392. Faubion, James (ed.) New York: The New Press.

Foucault, Michel (2000)

Governmentality. Teoksessa Faubion, James (ed.) Essential Works of Foucault 1954-1984. Volume Three, 201-222. New York: The New Press.

Frazer, Nancy (2006) Transnationalising the Public Sphere. http://www.republicart.net/disc/publicum/fraser01_en.htm, linkki tarkistettu 21.1.2006.

FT (2005a) European Opinion Leaders Survey 2003. www.ft.com/mediakit, linkki tarkistettu 19.8.2005.

FT (2005b)

The FT audience in the UK. The FT audience in Europe. The FT audience in Asia. www.ft.com/toolkit, linkki tarkistettu 19.8.2005.

Gordon, Colin (1991)

Governmental Rationality: An Introduction. Teoksessa Burchell, Graham; Gordon, Colin \& Miller, Peter (eds.) The Foucault Effect. Studies in Governmentality, 1-52. London: Harvester Wheatsheaf.

Habermas, Jürgen (1999)

The European Nation-State and the Pressures of Globalisation. New Left Review 1(23): 46-59.

Hall, Catherine (2002)

Civilising Subjects. Metropole and Colony in the English Imagination 1830-1867. Cambridge: Polity Press.

Hamelink, Cees (1995)

World Communication. Disempowerment \& Self-empowerment. London: Zed Books.

Hardt, Michael \& Antonio Negri (2000)

Empire. Cambridge: Harvard University Press.

Harvey, David (2003)

The New Imperialism. Oxford: Oxford University Press.

Harvey, David (2005)

The Brief History of Neoliberalism. Oxford: Oxford University Press.

Hindess, Barry (1998)

Neo-Liberalism and the National Economy. Teoksessa M. Dean and B. Hindess (eds.) Governing Australia, Studies in Contemporary Rationalities of Government, Cambridge: Cambridge University Press, pp. 210226.

Hirst, Paul \& Grahame Thompson (1996) Globalization in Question, Cambridge: Polity Press.

Kantola, Anu (2001) Leaving public places: antipolitical and antipublic forces of the transnational economy. Javnost 8(1): 59-74. Kantola, Anu (2006)

On the dark side of democracy: the global imaginary of financial journalism. Teoksessa Cammaerts, Bart \& Carpentier, Nico (eds.) Reclaiming the media. Communication rights and democratic media rules. Intellect. IImestyy 2006.

Kynaston, David (1988)

The Financial Times. A Centenary History. London: Viking. 
Lähteenmäki-Smith, Kaisa (2000)

Liberalism and Its limits: Globalism beyond independence. Teoksessa Hakovirta, Harto (ed.) Globalism at the Crossroads. Wedges into Global Theory and Policy, 17-54. Helsinki: The Finnish Political Science Association.

Mann, Michael (2005)

Incoherent Empire. London: Verso.

Nasson, Bill (2004)

Britannia's Empire. Making a British World.Glouchestershire: Tempus.

Panitch, Leo (2000)

The New Imperial State. New Left Review, March/April 2000, 5-20.

Peters, John Durham (2005)

Courting the Abyss. Free Speech and the Liberal Tradition. Chicago: The University of Chicago Press.

Polanyi, Karl ([1944] 1971)

The Great Transformation. 11th printing. Boston: Beacon Press.

Porter, Bernhard (1996)

The Lion's Share. A Short History of British Imperialism 1850-1995 (3rd ed.). London: Longman.

Porter, Bernard (2004)

The Absent-Minded Imperialists. Empire, Society, and Culture in Britain. Oxford: Oxford University Press.

Rantanen, Terhi (1997)

The globalization of electronic news in the 19th century. Media, Culture and Society, Vol. 19, 605-620.

Robertson, Ronald (1992)

Globalization. Social Theory and Global Culture. London: Sage.

Rodrik, Dani (1997)

Has Globalization Gone Too Far? Washington: Institute for International Economics.

Rose, Nikolas (1999)

Powers of freedom. Reframing political thought. Cambridge: Cambridge University Press.

Sahlin-Andersson, Kerstin \& Lars Engwall (eds.) (2002)

The expansion of management knowledge. Stanford: Stanford University Press.

Said, Edward W. (1994)

Culture and Imperialism. London: Vintage.

Taylor, Charles (2004)

Modern Social Imaginaries. Durham: Duke University Press.

Touraine, Alan (1990)

The Idea of Revolution. Theory, Culture \& Society, Vol. 7, 121-141. 